\title{
ROADSIDE TREE-LINED ALLEYS IN WOLIN COMMUNE OPEN LANDSCAPE. PART I
}

\section{PRZYDROŻNE ALEJE W OTWARTYM KRAJOBRAZIE GMINY WOLIN. CZĘŚĆ I}

Department of Ecology, Environmental Protection and Management, West Pomeranian University of Technology, Szczecin, Poland

\begin{abstract}
Streszczenie. W latach 2016-2017 przeprowadzono badania dendrologiczno-krajobrazowe na wybranym obszarze (14 ha) gminy Wolin - w północno-zachodniej Polsce. Do badań wytypowano pięć alej, o łącznej długości $16 \mathrm{~km}$, zlokalizowanych pomiędzy leśnym korytarzem ekologicznym a Zalewem Szczecińskim. Celem pracy było potwierdzenie pełnienia przez te zadrzewienia funkcji przyrodniczych i ochronnych w rozumieniu definicji obszarów proekologicznych. Przeanalizowano także kompozycyjno-przestrzenne cechy przydroży. Badane aleje tworzyło siedem gatunków drzew na odcinkach 100-1800 m; najliczniejsze były: Maple (Acer platanoides) - 458 szt., Oak (Quercus robur) - 258, Linden (Tilia cordata) - 178. Pod względem walorów przyrodniczych najwyższe oceny osiągnął Common Maple (Acer platanoides) - 24-30 pkt oraz Linden (Tilia cordata) - 23-27 pkt, a wśród alej - kolejno nasadzenie nr II (26 pkt), nr I (22 pkt) oraz nr III i nr V (20 pkt). Brak objawów dewastacji drzew na terenach przydroży oraz obecność 15 turbin wiatrowych wskazuje na wysoką świadomość ekologiczną rolników, a także na zrozumienie potrzeb wykorzystywania energii odnawialnej. Ocenione funkcje ekologiczne alej oraz ich lokalizacja wskazują na ich znaczny wkład w zachowanie bioróżnorodności i funkcji ochronnych. Stan zdrowotny badanych alej określa brak istotnych czynników zagrażających. Pomiary biometryczne drzew w analizowanych alejach wykazały, że zadrzewione przydroża spełniają wymogi obszarów proekologicznych. Pomimo obecności turbin wiatrowych, będących silną dominantą wizualną, wysoko oceniono wartości badanego obszaru, głównie dzięki zróżnicowaniu kompozycyjno-przestrzennemu krajobrazu.
\end{abstract}

Key words: alley, ecological tree function, health condition.

Słowa kluczowe: aleje, funkcje ekologiczne drzew, stan zdrowotny.

\section{INTRODUCTION}

Based on legal and surface classification tree stands are considered single trees, bushes or their groups which are neither forests nor plantations, including the area where they occur and other flora elements of less than 0.1 ha (J. of L. 2004). Field trees and bushes, often associated with open agricultural landscapes, because of their diverse species composition, origin and form, can fulfil many usable, aesthetic and landscape functions (Gamrat and Kochanowska 1999; Zajączkowski et al. 2001; Karg 2003; Milton et al. 2015; Kamiński 2016).

Correspoding author - Adres do korespondencji: Elżbieta Dusza-Zwolińska, Department of Ecology, Environmental Protection and Management, West Pomeranian University of Technology, Szczecin, Juliusza Słowackiego 17, 71-434 Szczecin, Poland, e-mail: Elzbieta.Dusza@zut.edu.pl 
One of the most common forms met in Western Pomerania are roadside linear planted trees, which have quite a few complex functions in the natural environment protection and shaping. These characteristic trees also make up a functional system of interactions and connections of all elements of living and inanimate nature, sometimes creating a unique ecosystem differentiated by habitat conditions: the degree of soil humidity, the inclination or substrate exposure (Gamrat and Kochanowska 2005; Wróbel et al. 2009; Gamrat et al. 2011; Dusza and Gamrat 2016).

Trees can also be considered pro ecological areas (EFA - Ecological Focus Area), or else surface elements of crop fields with a positive effect on the climate and the environment, such as hedges, freestanding trees, linear and group trees, ponds and balks. The main objective for these areas to exist is to increase the biodiversity in the agrarian landscape and to strengthen the biocenotic function (EFA 2016).

Wolin Commune is typically agricultural, as the farmlands make up more than $41 \%$ of its area. A significant part of the commune is also taken up by forest areas $-22 \%$. The area studied is an island of arable land under the impact of two extreme factors, arising from the proximity of the Szczecin Lagoon (from the west) and the forest ecological corridor (from the east). The studied roadside, owing to the close neighbourhood of the "Wolińskie Woodlands Goleniowska Forest” (KPn-32A) ecological corridor, and the location in the „Szczecin Lagoon” covered by Natura 2000 project (PLB 320009), are an important element to maintain the biodiversity of these agricultural landscape areas. An additional factor to determine the significant protective and landscape function of roadside trees in this area is the existence of 15 wind farms belonging to „Zagórze Windmill Farm” in the area under study. Their presence confirms strong winds from the Szczecin Lagoon. It can therefore be recognized that the tree-lined roadsides under study are valuable environments to reduce the adverse eolian impact to which farmlands are exposed. It has been assumed that the ever-growing ecological awareness of farmers in meeting the guidelines of good agricultural practice, among other things, by the lack of littering and devastation of tree belts (Duer et al. 2004; Józefczuk 2012; Antolak and Krawiecka 2014) will contribute to the preservation of high health and landscape values of the alleys under study.

The purpose of the study is to confirm the biocenotic and protective function of the field roadside trees is fulfilled in terms of the pro-ecological areas definition with an attempt to valorize their landscape value. The evaluated health values of trees, their dendrological, natural and cultural value, will serve to evaluate the degree of differentiation of alley values. A composition and spatial analysis of the alleys under study will also be carried out.

\section{MATERIAL AND METHODS}

Between 2016 and 2017, a dendrological and soil survey was conducted (part I and II respectively) in the selected area of Wolin commune - in northwestern Poland, in the West Pomeranian Province. This paper presents the results of the dendrological studies. A detailed analysis of soils and herb vegetation is to be the subject of another publication, Part II. 
The study covered five roadside alleys of a total length of $16 \mathrm{~km}$ (Table 3), located in the commune of Wolin, within the following villages: Recław, Wiejkowo, Wiejkówko, and Koniewo (Fig. 1). Selected roadside alleys are typical for the rural landscape of the Western Pomerania communities.

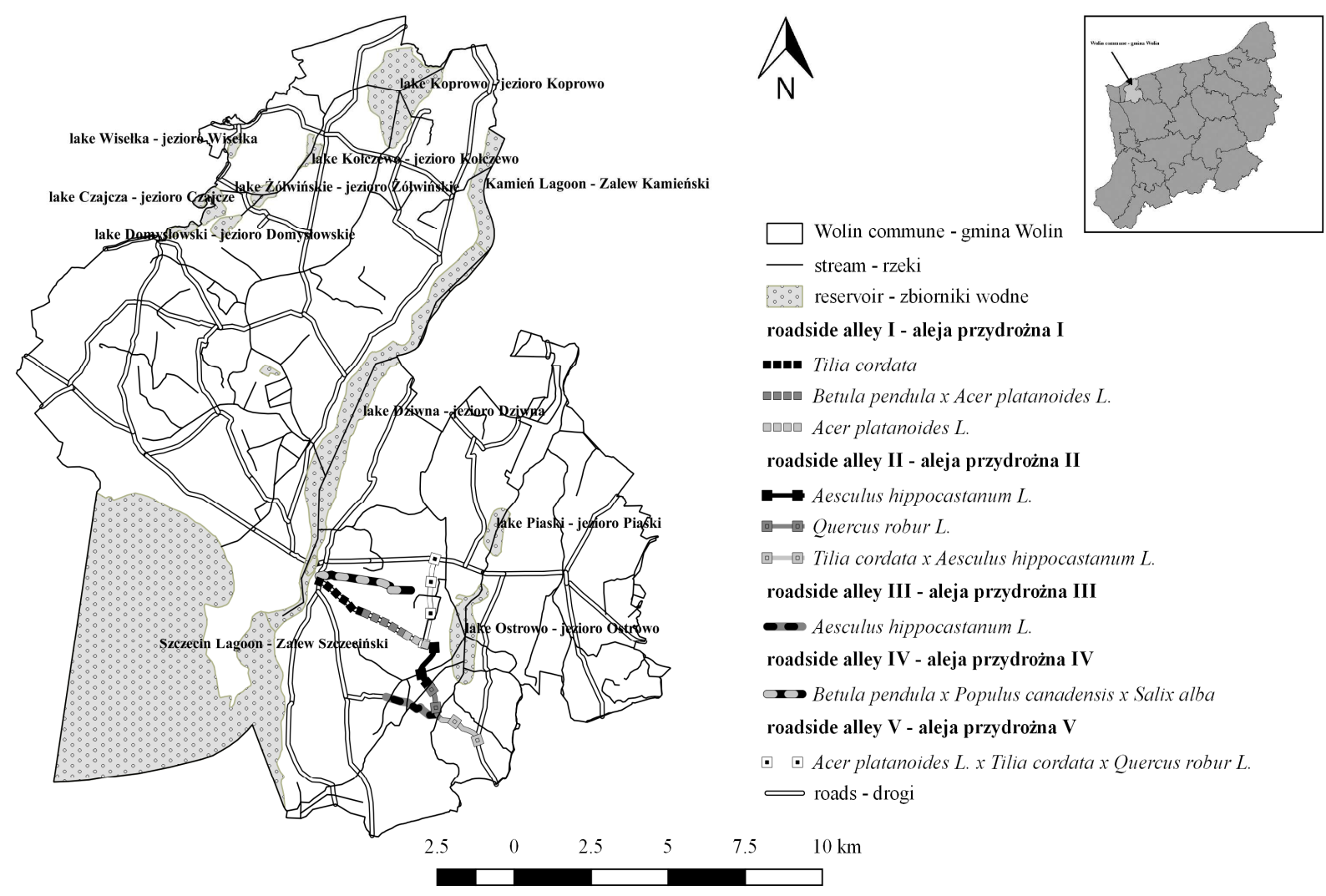

Fig. 1. Localization of the roadside avenues within the area of Wolin municipality Ryc. 1. Lokalizacja badanych alej przydrożnych na obszarze gminy Wolin

The characteristics of the roadside trees studied take into account:

1. Biometric measurements of the dominant species of trees, i.e. the species, forming a section of a given alley, made according to generally accepted principles (minimum, maximum and mean values for the species with the occurrence of $>10$ ), at randomly selected specimens - on both sides of the alley (Table 2):

- trunk circumference at $1.3 \mathrm{~m}$ height [cm],

- height of trees [m],

- crown width [m],

- trees span in the line,

- tree health condition determined by the method of Dusza and Gamrat (2016), whose criteria are presented in Table 1. 
Table 1. Criteria for evaluating the health condition of trees in roadside alleys

Tabela 1. Kryteria oceny stanu zdrowotnego drzew w badanych alejach przydrożnych

\begin{tabular}{ll}
\hline $\begin{array}{l}\text { Points } \\
\text { Punkty }\end{array}$ & \multicolumn{1}{c}{$\begin{array}{c}\text { Criteria for evaluating the health condition of trees } \\
\text { Charakterystyka kryteriów oceny stanu zdrowotnego }\end{array}$} \\
\hline 5 & $\begin{array}{l}\text { no visible damage, healthy trunk, correct structure, property shaped and healthy crown } \\
\text { bez widocznych uszkodzeń, zdrowy pień, prawidłowy pokrój, prawidłowo ukształtowana i zdrowa } \\
\text { korona }\end{array}$ \\
\hline 4 & \begin{tabular}{l} 
few traces of trunk damage, mainly surface shortages, well-shaped standard form, healthy rather \\
well maintained and shaped crown, few dry elements, correctly healed pruning cuttings \\
nieliczne uszkodzenia pni, głównie ubytki powierzchniowe, dobrze ukształtowana forma pienna, \\
zdrowa, dość dobrze zachowana i/ lub ukształtowana korona, nieliczny posusz, prawidłowo \\
zabliźnione miejsca cięć pielęgnacyjnych \\
\hline 3
\end{tabular}$\quad \begin{array}{l}\text { broken branches, trunk bark damaged in some places at the base, woodpeckers' holes, } \\
\text { disturbed standard form, reduced crown, excessive crown cutting, well visible dry elements } \\
\text { połamane konary, miejscami uszkodzenia kory pnia u podstawy, dziuple, zaburzona forma } \\
\text { pienna, zredukowana korona, nadmierne cięcia korony, mocno widoczny posusz }\end{array}$ \\
\hline 2 & $\begin{array}{l}\text { partly dead or very weakened, broken and undercut branches, trunk bark damaged on large } \\
\text { areas at numerous trees, vast trunk damage drying branches, woodpeckers' holes } \\
\text { częściowo martwe lub silnie osłabione, połamane i popodcinane konary, uszkodzenia kory pnia } \\
\text { na dużych powierzchniach u licznych okazów drzew, rozległe uszkodzenia pnia, zasychające } \\
\text { konary, dziuple }\end{array}$ \\
\hline 1 & $\begin{array}{l}\text { dead trees, partly dry, no trees, remains of rootstock or trunk } \\
\text { drzewa martwe, częściowo suche, brak drzewa - pozostałość karpy lub pnia }\end{array}$ \\
\hline &
\end{tabular}

2. The natural qualities of the dominant tree species according to the score:

- trees of the size close to the minimum size of monuments of nature (according to Kasprzak 2005) [3 pts. - more than 5 trees present in an alley with dimensions close to the monument of nature, 2 points - presence of more than 3 trees in an alley with dimensions close to a monument of nature, 1 point - presence of one tree in an alley close to a monument of nature, 0 - none] (value A - Table 4);

- functioning as proecological areas according to EFA (2016) based on the crown width, according to the maximum and minimum classification [5 pts. $-30-25 \mathrm{~m}$ of circumference, 4 pts $25-20$ m, 3 pts $20-15$ m, 2 pts $15-10$ m, 1 pt $<10$ m] (value B -Table 4);

- biocenotic, as bee-products, therapeutic, wind-proof, anti-erosion, [each ranging from 2 to 0 points] (Zajączkowski et al. 2001) (values C, D, E, I, J, L - Table 4);

- resistance to environmental factors [3 pts - most resistant, 2 - medium resistant, 1 - least resistant] (Łukasiewicz 2010) (K value - Table 4);

- tree trunks dimensions grouped, according to decreasing mean values of circumference [5 pts 500-400 cm, 4 pts $400-300$ cm, 3 pts 300-200 cm, 2 pts 200-100 cm, 1 pt $<100 \mathrm{~cm}$ ] ( $G$ value - Table 4).

The evaluation of the natural valorisation of the alleys under study was carried out, according to the author's own classification, taking into account the maximum values obtained, denoting valuable natural alleys (30 points), to the minimum values characterizing the alleys of reduced natural value (15 points).

3. Location, neighbourhood and type of roadside alleys under study (Table 3):

- location of alley [geographic direction],

- planting type [2 points - multi-row, 1 pt - single row],

- length [m], 
- number of trees in the alley [pcs]

- width of tree stand [m],

- trees spacing in a row [m],

- cover of the shrubs - average values [\%],

- type of road surface was classified according to the value of the roadside habitat from anthropogenic to natural forms [ 4 points - field road, 3 - gravel, 2 - cobbled, 1 - asphalt);

4. Landscape characteristics: alleys spatial composition as utility (windbreak) function and landscape function (taxons, section density of planting); view connections in the open landscape.

\section{RESULTS AND DISCUSSION}

Biometric characteristics of dominant tree species. Field studies have shown that the roadside tree alleys are made up of 10 tree species: Oak (Quercus robur L.), Gray Alder (Alnus glutinosa Gaertn.), Silver Birch (Betula pendula Roth), European Ash (Fraxinus excelsior L.), Canadian Poplar (Populus x canadensis Moench), Silver Willow (Salix alba L.), Horse-Chestnut (Aesculus hippocastanum L.), Common Maple (Acer platanoides L.), Sycamore (Acer pseudoplatanus L.), Linden (Tilia cordata Mill.) - Fig. 2.
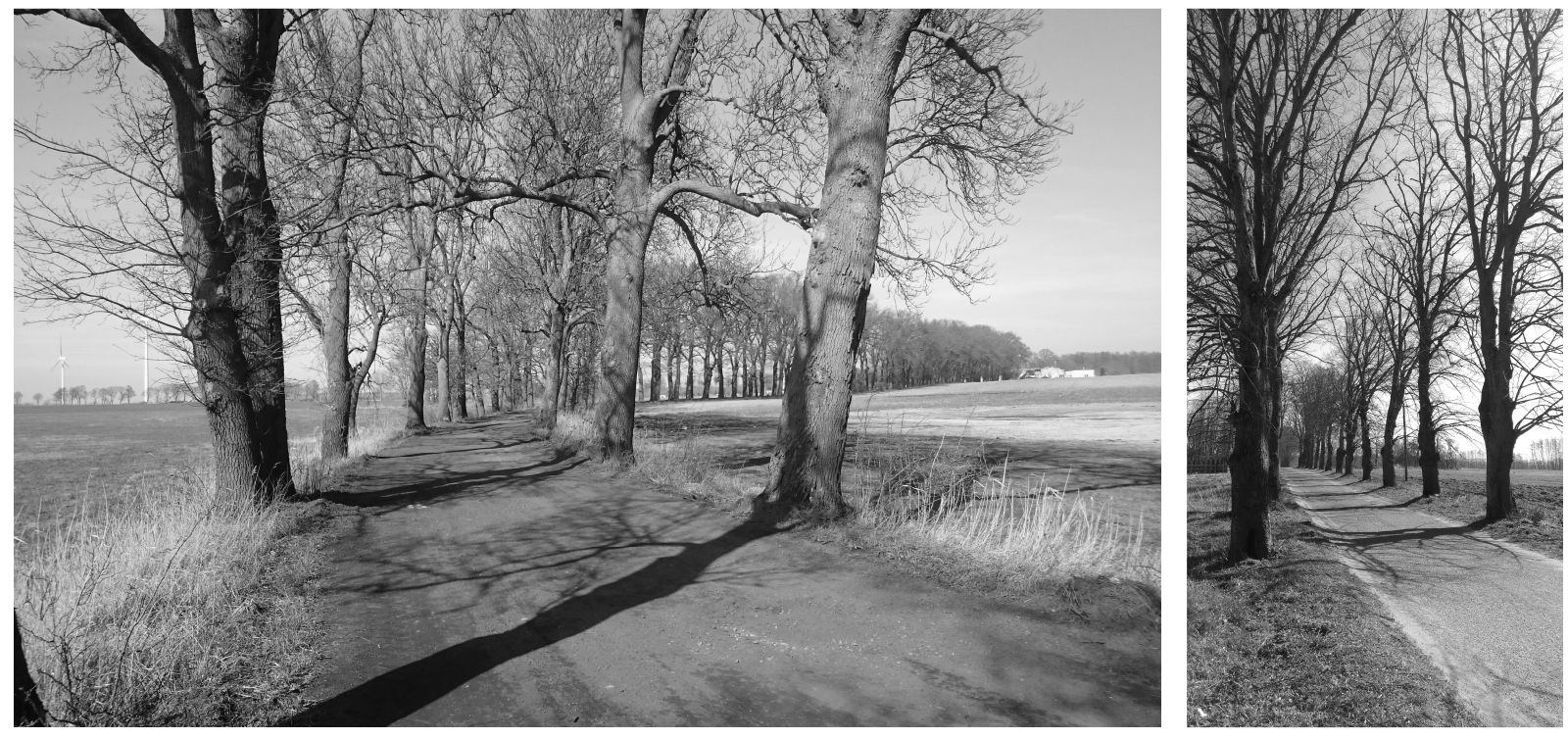

Fig. 2. Selected avenue arrangements within the area of Wolin commune (author: E. Dusza-Zwolińska, E. Saran)

Ryc. 2. Wybrane układy alejowe na terenie gminy Wolin (autor: E. Dusza-Zwolińska, E. Saran)

Investigating eight roadside alleys in Dobrzany and Suchań communes (West Pomeranian Province), Gamrat et al. (2011) identified 15 species that made part of the line tree species. Kubus (2011), analysing eight roadside tree stands of the West Pomeranian Province obtained similar results. He identified 14 species, forming alleys. The most common of the species that make up the alleys in the Commune of Wolin, are: Common Maple -458 pcs, Oak (Quercus robur) - 258 pcs, Linden (Tilia cordata) - 178 pcs and horse chestnut (Aesculus hippocastanum) - 112 pcs. They are indigenous species or considered as such, treated as familiar, even in the rural landscape of Pomerania, often used to form alleys. Only 
one species of foreign origin, Canadian Poplar (Populus $\mathrm{x}$ canadensis) was identified as an invasive tree species. Its share was insignificant, because within the five roadside alleys under study, only 23 trees of this species were identified. During their studies on roadside alleys of the Dywita Commune (Varmian \& Masurian Province), Dynowski et al. (2016) also designated Canadian Poplar (Populus $\mathrm{x}$ canadensis) poplar as the most invasive species of the 22 linear tree species.

Roadside tree stands as proecological areas. The complexity of the functions fulfilled by tree and bush clusters gives the right to consider linear tree stands as proecological areas similarly to small ponds and grasslands (Table 2). To classify linear tree stands as ecofriendly areas their crown diameter needs to exceed $4 \mathrm{~m}$. Tree-lined roadsides can be considered ecologically active areas (EFA 2016) when they take up a lot of space in the vertical and horizontal directions. In the analysed alleys, the diameter of the crown was $8.4 \mathrm{~m}$ on average, i.e. twice as wide as the above definition assumes. The maximum values for the crowns of the trees under study were even higher, and amounted on average to $10.6 \mathrm{~m}$. Trees spacing in the lane, i.e. the distance from the centre of the trunk to the centre of the neighboring tree was $9 \mathrm{~m}$ on average, and the minimum spacing was $7 \mathrm{~m}$.

Table 2. Characteristics of biometric measurements related to dominant tree species in roadside trees under study

Tabela 2. Charakterystyka pomiarów biometrycznych dominujących gatunków drzew w badanych zadrzewieniach przydrożnych

\begin{tabular}{|c|c|c|c|c|c|c|}
\hline \multirow{2}{*}{$\begin{array}{l}\text { Number } \\
\text { of alley } \\
\text { Numer } \\
\text { alei }\end{array}$} & \multirow{2}{*}{$\begin{array}{l}\text { Dominant } \\
\text { species } \\
\text { Gatunek } \\
\text { dominujący }\end{array}$} & \multirow{2}{*}{$\begin{array}{l}\text { Number } \\
\text { of trees } \\
\text { Liczba } \\
\text { drzew }\end{array}$} & $\begin{array}{c}\text { Tree } \\
\text { circumference } \\
\text { Obwód drzewa }\end{array}$ & $\begin{array}{l}\text { Height of trees } \\
\text { Wysokość } \\
\text { drzewa }\end{array}$ & $\begin{array}{l}\text { Crown width } \\
\text { Średnica } \\
\text { korony }\end{array}$ & $\begin{array}{c}\text { Trees spacing in } \\
\text { a row } \\
\text { Rozstaw w linii }\end{array}$ \\
\hline & & & \multicolumn{4}{|c|}{$\begin{array}{l}\text { Value maximum/ minimum/ average } \\
\text { Wartość maksimum/ minimum/ średnia }[\mathrm{m}]\end{array}$} \\
\hline \multirow[t]{5}{*}{1} & Tc & 60 & $3.20 / 1.31 / 2.23$ & $10 / 6 / 7$ & $16 / 7 / 9$ & $14 / 7 / 9$ \\
\hline & Apl & 359 & 3.36/2.01/2.39 & $12 / 6 / 8$ & $8 / 4 / 5$ & $15 / 5 / 8$ \\
\hline & $\mathrm{Pc}$ & 10 & $2.20 / 2.12 / 2.16$ & $11 / 9 / 10$ & $14 / 10 / 12$ & $15 / 13 / 12$ \\
\hline & $\mathrm{Bp}$ & 20 & $3.26 / 1.27 / 1.39$ & $8 / 6 / 7$ & $8 / 4 / 5$ & $15 / 5 / 9$ \\
\hline & Aps & 29 & $2.14 / 1.98 / 2.06$ & $11 / 5 / 8$ & $8 / 4 / 5$ & $12 / 5 / 8$ \\
\hline \multirow[t]{4}{*}{ II } & Ah & 101 & $2.90 / 2.76 / 2.84$ & $8 / 6 / 7$ & $7 / 6 / 7$ & $15 / 10 / 12$ \\
\hline & Qr & 225 & $3.95 / 1.30 / 2.74$ & $15 / 9 / 12$ & $18 / 8 / 13$ & $17 / 10 / 13$ \\
\hline & Tc & 70 & $1.57 / 1.23 / 0.40$ & $12 / 9 / 10$ & $8 / 6 / 7$ & $14 / 7 / 9$ \\
\hline & Apl & 18 & $5.02 / 4.95 / 4.98$ & $15 / 15 / 15$ & $30 / 28 / 29$ & $12 / 5 / 8$ \\
\hline \multirow[t]{3}{*}{ III } & $\mathrm{Ah}$ & 11 & $3.24 / 2.95 / 3.09$ & $8 / 6 / 6$ & $6 / 5 / 5$ & $14 / 6 / 10$ \\
\hline & Qr & 13 & $2.20 / 1.78 / 1.67$ & $8 / 6 / 6$ & $8 / 6 / 7$ & $14 / 6 / 10$ \\
\hline & Apl & 16 & $1.80 / 1.65 / 1.72$ & $8 / 6 / 6$ & $8 / 6 / 7$ & $14 / 6 / 10$ \\
\hline IV & $\mathrm{Bp}$ & 11 & $1.40 / 1.33 / 1.37$ & $8 / 6 / 7$ & $8 / 4 / 5$ & $8 / 5 / 7$ \\
\hline \multirow[t]{6}{*}{$\mathrm{V}$} & Aps & 18 & $2.12 / 1.65 / 1.95$ & $9 / 4 / 7$ & $8 / 3 / 6$ & $12 / 5 / 8$ \\
\hline & Apl & 65 & $2.54 / 2.01 / 2.29$ & $13 / 6 / 10$ & $12 / 6 / 9$ & $125 / 8$ \\
\hline & Qr & 20 & $1.92 / 1.45 / 1.68$ & $6 / 4 / 5$ & $6 / 6 / 6$ & $15 / 10 / 13$ \\
\hline & Tc & 48 & $2.26 / 1.35 / 1.43$ & $10 / 7 / 8$ & $8 / 6 / 7$ & $12 / 5 / 9$ \\
\hline & $\mathrm{Bp}$ & 17 & $1.28 / 0.86 / 1.07$ & $8 / 6 / 7$ & $8 / 4 / 5$ & $10 / 6 / 8$ \\
\hline & $\mathrm{Pc}$ & 16 & $2.50 / 1.24 / 1.87$ & $11 / 9 / 10$ & $12 / 10 / 11$ & $17 / 12 / 14$ \\
\hline
\end{tabular}

Apl - Acer platanoides, Aps - Acer pseudoplatanus, Ah - Aesculus hippocastanum, Bp - Betula pendula, Pc Populus xcanadensis, Qr - Quercus robur, Sa - Salix alba, Tc - Tilia cordata. 
An important aspect with an impact on the functions of the trees is also their length (Table 3). There were five tree-lined roadsides identified for study at the chosen area of a total length of $16 \mathrm{~km}$. The maximum length of the tree-lined roadside alleys was $4300 \mathrm{~m}$ (alley No. 1) and the minimum one $1849 \mathrm{~m}$ (alley No. III). Despite of their relatively small dimensions, Wolin's alleys belong to the longest ones described. In the agricultural area of Suchan Commune (West Pomeranian Province) Gamrat et al. (2011) did not find such long forms of tree-lined roadsides. The longest alley presented by the authors of the study was about one half shorter (2 km) - Table 2. Janczak-Pieniążek (2013) obtained similar results by studying the condition of sweet cherries alleys in a chosen part of the Opole Province. The observations by Dynowski et al. (2016) in the agricultural Commune of Dywity (Varmian and Masurian Province) were similar. There, the length of the alleys under study was six times lower than the tree-lined roadside alleys found in the area of Wolin commune.

The health condition of trees was classified between good and sufficient (3.6 points). Less satisfactory results were mainly awarded to chestnut lanes, which were devastated by careless pruning of roadside trees and old Canadian poplar specimens with numerous broken lateral branches (most likely due to eolian activity). In consequence, the whole tree structure was deformed. No signs of littering and only slight local devastation of roadside tree trunks, would indicate high environmental awareness among farmers, among other things, while fulfilling the assumptions of good agricultural practice. The pro-ecological attitude of local residents is also reflected in the understanding of the needs to use renewable energy, as there are as many as 15 wind turbines in the surrounding fields (Jak naprawdę żyje się w cieniu wiatraków, http://domrel.pl/_publikacje/KG_Ekspres_Legnicki-22.06.11.pdf.), which may prove to be the cause for sustainable development of these areas.

Location, neighborhood and type of roadside alleys under study (Table 3).

Table 3. Characteristics of physical and habitat conditions (mean values) of the alleys under study Tabela 3. Charakterystyka warunków fizycznych i siedliskowych (wartości średnie) badanych alej

\begin{tabular}{|c|c|c|c|c|c|c|c|c|}
\hline \multirow[b]{2}{*}{$\begin{array}{l}\text { Number } \\
\text { of } \\
\text { alley } \\
\text { Numer } \\
\text { alei }\end{array}$} & \multicolumn{5}{|c|}{$\begin{array}{l}\text { Physical conditions } \\
\text { Warunki fizyczne }\end{array}$} & \multicolumn{3}{|c|}{$\begin{array}{c}\text { Habitat conditions } \\
\text { Warunki siedliskowe }\end{array}$} \\
\hline & $\begin{array}{c}\text { geographic } \\
\text { direction } \\
\text { pozycja }\end{array}$ & $\begin{array}{l}\text { number } \\
\text { of trees in } \\
\text { the alley } \\
\text { liczba } \\
\text { drzew }\end{array}$ & $\begin{array}{c}\text { number of } \\
\text { dominat } \\
\text { trees } \\
\text { liczba } \\
\text { dominu- } \\
\text { jących } \\
\text { drzew } \\
\end{array}$ & $\begin{array}{l}\text { length of } \\
\text { alley } \\
\text { długość } \\
\text { alei } \\
\text { [m] }\end{array}$ & $\begin{array}{l}\text { the width } \\
\text { of the crown } \\
\text { of trees } \\
\text { szerokość } \\
\text { koron drzew } \\
\text { [m] }\end{array}$ & $\begin{array}{l}\text { trees } \\
\text { spacing } \\
\text { rozstaw } \\
\text { drzew } \\
{[\mathrm{m}]}\end{array}$ & $\begin{array}{l}\text { health } \\
\text { status } \\
\text { of alley } \\
\text { stan } \\
\text { zdrowotny } \\
\text { alei [pkt] }\end{array}$ & $\begin{array}{c}\text { cover } \\
\text { of the } \\
\text { shrubs } \\
\text { zwarcie } \\
\text { krzewów } \\
\text { [\%] }\end{array}$ \\
\hline 1 & W-E/S & 478 & 5 & 4300 & 7 & 9 & 3 & 3 \\
\hline II & S/E-N & 414 & 4 & 4064 & 14 & 11 & 4 & 3 \\
\hline III & W-E/S & 40 & 3 & 1849 & 6 & 10 & 3 & 0 \\
\hline IV & W-E & 22 & 1 & 3183 & 5 & 7 & 3 & 16 \\
\hline V & S-N & 187 & 6 & 2713 & 7 & 7 & 4 & 20 \\
\hline
\end{tabular}

According to Nowak-Rząsa (2010), to fulfil biocenotic functions and to be considered a pro-ecological area, tree lines shall have the minimum length of at least $50 \mathrm{~m}$. As to single-row tree stands, the width of the line made up by trees is also important - their width of $2.5 \mathrm{~m}$ is 
considered to be optimal. The tree species composition is also of importance. This shall be adapted to the local habitat conditions and native species shall be used. Anywhere the local ecotypes of trees and shrubs allow that, the share of melliferous and fruit trees and bushes is to be ensured (Nowak-Rząsa 2010).

The regulation on technical conditions to be met by public roads and their location stipulates in $\S 53$ as follows:

1. The width of the green belt shall be at least $3.0 \mathrm{~m}$, if it is a row of trees, hedges or bushes, to ensure sufficient conditions for its vegetation and care.

2. Trees in the lane should be located in such a way as not to cause road surface damage nor hinder pedestrian use of pavement, especially by those disabled, during their vegetation (Journal of Laws 1999). The type of surface also affects the appearance and functions of the tree stands. Roadside tree lines under study are appropriately integrated into spatial landscape, the stress factors direction taken into account. Eolian activity shall be particularly important in this area. The location of tree stands allows the area under study to neutralize the negative impact of the wind. When selecting the species for planting along roads in such exposed area their ability to brake wind speed shall be taken into account, among other things; limp branches of trees do this more efficiently than rigid ones, and birches, for example, are such species. They made up surveyed sections of the areas under study.

Analysis of natural conditions of the alleys under study. The basic functions of alleys in the environment are well known. In open spaces - like the area under study - the protective features are particularly valuable for the herbaceous vegetation and the fauna associated with it, especially through the creation of ecological corridors (Table 4). Given the species composition of the stands of tree lines, the high share of linden and white willow, they are potential habitats for the hermit beetle (Dusza and Gamrat 2016; Żróbek-Sokolnik et al. 2016). In line with the well understood biocenotic functions, the most common feature being the enhanced rural biodiversity, tree lines also have very important protective functions (Nowak-Rząsa 2010; Kiss et al. 2015; Öztürk and Bozdoğan 2015). The study by Tóth et al. (2016) pointed to Black Locust as a prevailing species to create good wind-barriers, mainly due to its rapid growth (1m per year), level compactness and proper crown. However, Black Locust has not been identified in the area, which, however, does not diminish the protective (wind resistant) function of roadside trees.

Common Maple (Acer platanoides) - (24-30 points) and Linden (Tilia cordata) - (23-27 points) had the highest score as to natural values and among alleys No II (26 points), and subsequently I (22 points) and III and V (20 points). In alleys I and II, eight (and respectively 5) species of dimensions close to monuments of nature were identified in line with high tree circumferences. Common Maple (Acer platanoides) proved to be the most abundant species among monumental-dimensions trees, and the widest trunks were measured at Silver Willow (Salix alba) of $545 \mathrm{~cm}$, Common Maple (Acer platanoides) of $495 \mathrm{~cm}$ and Oak (Quercus robur of $395 \mathrm{~cm}$ (Table 5). 
Table 4. Characteristics of ecological conditions of dominant tree species in the alleys under study

Tabela 4. Charakterystyka warunków ekologicznych dominujących gatunków drzew w badanych alejach

\begin{tabular}{|c|c|c|c|c|c|c|c|c|c|c|c|c|c|}
\hline \multirow{2}{*}{$\begin{array}{c}\text { Number of } \\
\text { alley } \\
\text { Numer alei }\end{array}$} & \multirow{2}{*}{$\begin{array}{c}\text { Types of trees } \\
\text { Gatunki } \\
\text { drzew }\end{array}$} & \multicolumn{12}{|c|}{ Features of trees - Cechy drzew } \\
\hline & & A & B & C & D & $E$ & $\mathrm{~F}$ & G & $\mathrm{H}$ & I & $\mathrm{J}$ & $\mathrm{K}$ & $\mathrm{L}$ \\
\hline \multirow{5}{*}{1} & Tc & 3 & 1 & 2 & 2 & 2 & 1 & 3 & 4 & 2 & 1 & 3 & 2 \\
\hline & Apl & 3 & 1 & 2 & 1 & 0 & 1 & 3 & 4 & 2 & 1 & 3 & 2 \\
\hline & $\mathrm{Pc}$ & 0 & 2 & 0 & 1 & 0 & 2 & 3 & 4 & 2 & 2 & 2 & 0 \\
\hline & $\mathrm{Bp}$ & 0 & 1 & 0 & 1 & 1 & 2 & 2 & 3 & 2 & 1 & 2 & 0 \\
\hline & Aps & 1 & 1 & 2 & 2 & 0 & 1 & 2 & 3 & 2 & 2 & 3 & 2 \\
\hline \multirow{4}{*}{ II } & Ah & 3 & 1 & 1 & 2 & 1 & 1 & 3 & 3 & 2 & 0 & 3 & 2 \\
\hline & Qr & 3 & 2 & 1 & 1 & 1 & 1 & 3 & 4 & 2 & 2 & 3 & 2 \\
\hline & Tc & 0 & 1 & 2 & 2 & 2 & 1 & 2 & 4 & 2 & 1 & 3 & 2 \\
\hline & Apl & 2 & 5 & 2 & 1 & 0 & 1 & 5 & 5 & 2 & 1 & 3 & 2 \\
\hline \multirow{3}{*}{ III } & Ah & 2 & 1 & 1 & 2 & 1 & 1 & 4 & 3 & 2 & 0 & 3 & 2 \\
\hline & Qr & 0 & 1 & 1 & 1 & 1 & 1 & 2 & 4 & 2 & 2 & 3 & 2 \\
\hline & Apl & 0 & 1 & 2 & 1 & 0 & 1 & 2 & 3 & 2 & 1 & 3 & 2 \\
\hline IV & $\mathrm{Bp}$ & 2 & 1 & 0 & 1 & 1 & 2 & 2 & 3 & 2 & 1 & 2 & 0 \\
\hline \multirow{6}{*}{ V } & Aps & 2 & 1 & 2 & 2 & 0 & 1 & 2 & 4 & 2 & 2 & 3 & 2 \\
\hline & Apl & 3 & 1 & 2 & 1 & 0 & 1 & 3 & 4 & 2 & 1 & 3 & 2 \\
\hline & Qr & 0 & 1 & 1 & 1 & 1 & 1 & 2 & 4 & 2 & 2 & 3 & 2 \\
\hline & Tc & 0 & 1 & 2 & 2 & 2 & 1 & 2 & 4 & 2 & 1 & 3 & 2 \\
\hline & $\mathrm{Bp}$ & 0 & 1 & 0 & 1 & 1 & 2 & 1 & 3 & 2 & 1 & 2 & 0 \\
\hline & $\mathrm{Pc}$ & 0 & 2 & 0 & 1 & 0 & 2 & 2 & 3 & 2 & 2 & 2 & 0 \\
\hline
\end{tabular}

A - values of monuments of nature - walory pomników przyrody, B - values of proecological area, according to crown width - walory obszaru proekologicznego wg szerokości korony, C - biocenotic values - walory biocenotyczne, D - nectariferous values - walory nektarodajne, $\mathrm{E}$ - therapeutic values - walory terapeutyczne, F - aesthetic values - walory estetyczne, $G$ - values of trunk dimensions - walory wielkości pni, $H$ - health values - walory zdrowotne, I - value of forms (rows) - walory formy (rzędowość), $\mathrm{J}$ - anti-erosion values - walory przeciwerozyjne, $\mathrm{K}$ - resistance values - walory odporności, $\mathrm{L}$ - wind-protective values - walory przeciwwietrzne. Other explanations see Table 2 - Pozostałe objaśnienia zob. tab. 2.

Table 5. List of tree species of size similar to monuments of nature

Table 5. Lista gatunków drzew o rozmiarach zbliżonych do wymiarów pomników przyrody

\begin{tabular}{|c|c|c|c|c|c|}
\hline \multirow{3}{*}{$\begin{array}{l}\text { Name of species } \\
\text { Nazwa gatunku }\end{array}$} & \multicolumn{5}{|c|}{ Number of alley - Numer alei } \\
\hline & $\mathrm{I}$ & II & III & IV & $\mathrm{V}$ \\
\hline & \multicolumn{5}{|c|}{ Circumference - Obwód [cm] } \\
\hline Common Maple (Acer platanoides) & $\begin{array}{l}220,247, \\
331\end{array}$ & 495,502 & - & - & $\begin{array}{l}254,231, \\
228\end{array}$ \\
\hline $\begin{array}{l}\text { Horse-Chestnut } \\
\text { (Aesculus hippocastanum) }\end{array}$ & - & $280,281,282$ & 324,295 & - & - \\
\hline Sycamore (Acer pseudoplatanus) & 214 & - & - & - & 206,221 \\
\hline Linden (Tilia cordata) & $\begin{array}{l}311,320 \\
321\end{array}$ & - & - & - & - \\
\hline Oak (Quercus robur) & - & $320,281,395$ & - & - & - \\
\hline Canadian popular (Populus x canadensis) & - & - & - & 366 & - \\
\hline Silver willow (Salix alba) & - & - & - & 545 & - \\
\hline
\end{tabular}

Composition and spatial analysis of alleys under study. When considering the functions of trees and bushes at the landscape level, their ecological function shall be taken into account. In addition to the ecological dimension (e.g. habitat, age and species diversity), 
the diversification of the landscape has also aesthetic dimension (composition: of landscape, forms of trees and bushes, elementary and individual) and cultural dimension - variety of creative activities, manner of landscape creating (Clare et al. 2006; Bożętka 2007; Szulczewska et al. 2014; Antolak and Krawiecka 2014).

In the landscape under study, the analysed alleys in terms of ecological values show great diversity. They are characterized primarily by the diversity of habitats of tree-lined roadsides. The alleys under study in the Commune of Wolin were located in the neighbourhood of a variety of pavements, starting from asphalt (alleys No I, and III), through cobblestones (alley II) and gravel roads (alley V), to field roads (alley IV). Trees and bushes growing in the alleys under study were on both sides of the road - 10 species were identified in all, seven of them were creating tree forming sections, i.e: Horse - Chestnut (Aesculus hippocastanus), Common Maple (Acer platanoides), Sycamore (Acer pseudoplatanus), Silver Birch (Betula pendula), Canadian Popular (Populus x Canadensis) and Oak (Quercus robur).

The aesthetic dimension of the tree stands fosters the recipient of the open space, in form of narrow lines of planted trees joining each other. The qualities are enhanced by individual trees: very tall specimens of Canadian Popular (Populus $\mathrm{x}$ canadensis) with monumental dimensions, or a section of pollarded old Silver Willow (Salix alba) specimens. A further composition of the alley systems describes a definite rhythm of contrasting trees planting (for example, linden and silver birch - alley No. 1). Although the trees are quite densely planted and are very close to the road, however, relatively insignificant traffic in these roads does not affect their health (mechanical damage). Pruning cuts are not drastic, either, and therefore, the shape of trees is close to natural. However, the cultural aspect can be criticized. The 15 wind turbines are artificial cultural elements in the landscape. Their high elements and location at the background of the line of the trees disturb the reception of the landscape openness. The hovering elements are referred to as a special form of ecological vandalism pointed against the emotional bonds of the humans with the surrounding landscape (Badora 2011; Pływaczewski 2015).

\section{CONCLUSIONS}

1. The evaluated ecological functions and their location indicated their significant contribution to the preservation of agricultural landscape biodiversity and the fulfilment of protective functions for field crops.

2. The health condition of the alleys shows no significant threat from anthropogenic factors.

3. The biometric measurements of the trees in the alleys under study and their functions proved that tree-lined roadsides meet the requirements for ecological areas.

4. High natural and ecological value of the roadside alleys studied within the area of Wolin community, indicate that they should be protected by law.

5. Despite of the presence of wind turbines, the value of the area under study has been highly evaluated, owing to the compositional and spatial diversity of the landscape. 


\section{REFERENCES}

Antolak M., Krawiecka E. 2014. Zabytkowe aleje przydrożne gminy wiejskiej Ostróda w percepcji dynamicznej uczestnika ruchu drogowego, w: Instrumenty kształtowania przestrzeni obszarów wiejskich. Red. M. Nowak, K. Pawlewicz, A. Szczepańska. Olsztyn, Wydaw. UWM Olsztyn, 85-94. [in Polish]

Badora K. 2011. Ocena wpływu farm wiatrowych na krajobraz - aspekty metodyczne i praktyczne [Assessment of wind farms impact upon the landscape - methodological and practical aspects]. Probl. Ekol. Kraj. 31, 6-1. [in Polish]

Bożętka B. 2007. Wybrane problemy waloryzacji zadrzewień i zakrzewień obszarów rolnych. Waloryzacja środowiska przyrodniczego w planowaniu przestrzennym [Some issues concerning evaluation of trees and bushes in farming landscapes. Methods of environmental assessment in physical planning]. Probl. Ekol. Kraj. 19, 117-127. ISBN 978-83-7531-005-4. [in Polish]

Clare T., Bunce R.G. 2006. The potential for using trees to help define historic landscape zones: a case study in the English Lake District. Landscape Urban Plan 74, 34-45.

Duer I., Fotyma M., Madej A. 2004. Kodeks dobrej praktyki rolniczej. Wyd. III. Warszawa, Ministerstwo Rolnictwa i Rozwoju Wsi, Ministerstwo Środowiska, 3-96. ISBN 83-88010-58-1. [in Polish]

Dusza E., Gamrat R. 2016. Hermit beetle's (Osmoderma eremita Scopoli, 1763) occurrence in roadside double row of willows. Acta Biol. 23, 35-45.

Dynowski P., Źróbek-Sokolnik A., Fenyk M.A. 2016. Aleje przydrożne gminy Dywity - przegląd i potrzeby uzupełnienia drzewostanów [Roadside tree alleys in dywity commune - overview and needs for stand of trees complementation]. Acta Sci. Pol., Formatio Circumiectus 15(4), 129-142. [in Polish]

EFA. 2016. Obszary proekologiczne - podstawowe informacje. Warszawa, Agencja Restrukturyzacji i Modernizacji Rolnictwa, 1. [in Polish]

Gamrat R., Kochanowska R. 1999. Charakterystyka zadrzewień śródpolnych na terenie gminy Dobra Szczecińska - ich znaczenie i problemy ochrony [Characteristic of midfield afforestation in Dobra Szczecińska municipality - they sygnificate and conservation problems]. Prz. Przyr. 10, 3-4,77-84. [in Polish]

Gamrat R., Kochanowska R. 2005. Zbiorowiska trawiaste zadrzewień przydrożnych w rejonie Gryfina [Grasses communities of roadside planting near Gryfino]. Łąk. Pol. 8, 61-70. [in Polish]

Gamrat R., Młynkowiak E., Podlasiński M. 2011. Aktualny stan alej przydrożnych proponowanych do ochrony w dwóch sąsiadujących gminach Dobrzany i Suchań w województwie zachodniopomorskim [Current condition of roadside tree alleys suggested for the protection in two neighbouring communes of Dobrzany and Suchań in the West Pomeranian voivodeship]. Ekol. Tech. 19, 3A, 209-214. [in Polish]

Jak naprawdę żyje się w cieniu wiatraków, http://domrel.pl/_publikacje/KG_Ekspres_Legnicki-22.06.11.pdf, access: 25.04.2017. [in Polish]

Józefczuk J. 2012. Drzewa przydrożne i ich rola, funkcje życiowe drzewa, komunikowanie kwestii związanych z drzewami społecznościom lokalnym, w: Drzewa w otwartym krajobrazie - instrukcja obsługi. Szkolenie z zakresu oceny stanu, pielęgnacji oraz podejmowania decyzji o wycince drzew, Legnickie Pole, 3-4.12.2012. Red. J. Józefczuk. Gorzów, NFOŚiGW, 31. [in Polish]

Kamiński W. 2016. Rola zadrzewień w kształtowaniu różnorodności biologicznej - wybrane aspekty prawne dotyczące ochrony zadrzewień. Suwałki, Xpression, 60. ISBN 978-83-934721-2-3. [in Polish]

Karg J. 2003. Zadrzewienia śródpolne, strefy buforowe i miedze. Program rolnośrodowiskowy. Wyd. 1. Warszawa, Bibl. Kraj. Progr. Rolnośrod., 28. ISBN 83-920037-3-X. [in Polish]

Kasprzak K. 2005. Ochrona pomników przyrody. Zasady postępowania administracyjnego. Wyd. 5. Poznań, Abrys, 132. [in Polish] 
Kiss M., Takacs A., Pogadacsas R., Gulyas A. 2015. The role of ecosystem services in climate and air quality in urban areas. Evaluating carbon sequestration and air pollution removal by street and park trees in Szeged (Hungary). Morav. Geogr. Rep. 23(3), 36-46.

Kubus M. 2010. Godne prawnej ochrony aleje przydrożne na Pomorzu Zachodnim. Część 2 [Roadside tree avenues in Western Pomerania worth legal protection. Part 2]. Rocz. PTD 58, 71-78. [in Polish]

Łukasiewicz S. 2010. Drzewa i krzewy polecane do obsadzeń ulicznych w miastach. Red. M. Drozdek. Sulechów, PWSZ, 313-315. [in Polish]

Milton S.J., Dean W.R., Sielecki L.E., Ree R. van der. 2015. The function and management of roadside vegetation (in: Handbook of road ecology). Eds. R. van der Ree, D.J. Smith, C. Grilo. Londyn, John Wiley \& Sons 46, 373-381.

Nowak-Rząsa M. 2010. Zadrzewienia śródpolne jako cenny element krajobrazów rolniczych [The field planting as a valuable element of the agricultural landscape]. Acta Sci. Pol., Administratio Locorum 9/4, 99-106. [in Polish]

Öztürk S., Bozdoğan E. 2015. The contribution of urban road trees on improving the air quality in an urban area. Fres. Environ. Bull. 24, 5a, 1822-1829.

Pływaczewski W. 2015. Degradacja krajobrazu jako szczególna forma wandalizmu ekologicznego kontrowersje wokół lokalizacji farm wiatrowych na obszarach wyróżniających się cennymi walorami naturalnymi kulturowymi, w: Wandalizm wobec dziedzictwa naturalnego i kulturowego. Red. W. Pływaczewski, S. Buczyński. Olsztyn, Katedra Kryminologii i Polityki Kryminalnej, 13-39. ISBN 978-83-62383-56-6. [in Polish]

Rozporządzenie Ministra Transportu i Gospodarki Morskiej z dnia 2 marca 1999 r. w sprawie warunków technicznych, jakim powinny odpowiadać drogi publiczne i ich usytuowanie. DzU z 1999 r., nr 43, poz. 430. [in Polish]

Szulczewska B., Giedych R., Borowski J., Kuchcik M., Sikorski P., Mazurkiewicz A., Staczyk T. 2014. How much green is needed for a vital neighbourhood? In search for empirical evidence. Land Use Policy 38, 330-345.

Tóth A., Kuczman G., Feriancová L. 2016. Species composition and diversity of non-forest woody vegetation along roads in the agricultural landscape. Lesn. Cas. For. J. 62, 56-66.

Ustawa z dnia 16 kwietnia 2004 r. o ochronie przyrody. DzU z 2004 r., nr 92, poz. 880. [in Polish]

Wróbel M., Chudecka J., Tomaszewicz T., Gałczyńska M. 2009. Contents of heavy metals in roadside soils and spatial distribution of metallophyte plant species on the roadsides of Szczecin lowland. Ecol. Chem. Eng. 16, 1-2, 91-98.

Zajączkowski K., Tałałaj Z., Węgorek T., Zajączkowska B. 2001. Dobór drzew i krzewów do zadrzewień na obszarach wiejskich. Warszawa, IBL, 78. ISBN 83-87647-25-X. [in Polish]

Zróbek-Sokolnik A., Dynowski P., Fenyk M.A. 2016. Aleje przydrożne gminy Dobre Miasto. Przegląd i potrzeby uzupełnienia drzewostanów [Roadside tree alleys Dobre Miasto commune. Overview and needs for stand of trees complementation]. Acta Sci. Pol., Administratio Locorum 15(1), 71-89. [in Polish]

Abstract. In the years 2016-2017, dendrological and landscape studies were carried out in the selected area of the Wolin commune. Five alleys with a total length of $16 \mathrm{~km}$ between the forest ecological corridor and the Szczecin Lagoon were selected for the study. The aim of the study was to confirm the fulfilment of the natural and protective functions of these trees in the definition of ecological areas. The compositional-spatial features of the roadside have also been analysed. The study trails consisted of seven tree species ranging from $100 \mathrm{~m}$ to $1800 \mathrm{~m}$, the most numerous of which were Acer platanoides (458) and Quercus robur (258). In terms of natural values, Acer platanoides (24-30 points) and Tilia cordata (23-27) gained the highest values, among the alleys - planting no II (26 points), I (22), III and V (20). The absence of traces of devastation of roadside trees and the presence of 15 wind turbines, would indicate a high ecological awareness of farmers and understanding for the use of renewable energy. Assessed ecological functions of alleys and their location indicated on their significant 
contribution to the conservation of biodiversity and protective functions. The health condition of the investigated alleys points out no significant threat factors. Biometric measurements of trees in the analysed alleys showed that the tree-lined roadside meets the requirements of ecological areas. Despite of the presence of wind turbines, which are strong visual dominant, the value of the studied area was highly valued, mainly due to the compositional and landscape diversity. 
